\title{
Pengaruh Tanah Timbunan Terhadap Daya Dukung Pondasi Telapak (Square Footing)
}

\section{Influence of Heap Soil on The Carrying Capacity of Square Footing Foundation}

\author{
Beni Deni Sitompul1), Irwan'2), \& Kamaluddin Lubis ${ }^{3)}$ \\ Program Studi Teknik Sipil, Fakultas Teknik \\ Universitas Medan Area, Indonesia \\ *Corresponding Email: benytompul.01@gmail.com
}

\begin{abstract}
ABSTRAK
Struktur bawah bangunan suatu konstruksi gedung terdiri dari pondasi dan lapisan tanah untuk mendukung beban konstruksi bagian atas. Kondisi tanah di bawah struktur sangat berkaitan dengan perilaku tanah itu sendiri ketika menerima beban, misalnya kegagalan yang terjadi pada sub-grade pondasi timbunan yakni tanah pondasi terlalu lunak sehingga daya dukung tanah dalam menahan beban timbunan kecil, akibatnya settlement yang terjadi terlalu besar. Maka lapisan tanah yang ada di bawah struktur tersebut haruslah kuat, stabil, aman, agar tidak mengalami penurunan, tidak mengalami patah, karena akan sulit untuk memperbaiki suatu sistem pondasi. Tujuan dalam penelitian ini adalah untuk mengetahui pengaruh tanah timbunan pada suatu pondasi telapak dan berapa besar penurunan yang ditimbulkan terhadap pondasi. Metode Plaxis D2 V20 adalah metode elemen hingga yang bertujuan dalam menganalisis dan mendesign bidang geoteknik. Pengambilan sampel tanah dilakukan di RS Wulan Windi Kota Medan, dengan menggunakan alat manual. Penyelidikan tanah timbunan bertujuan untuk mengetahui sifat dan karakteristik tanah timbunan yang dilakukan di Laboratorium Teknik Sipil Universita Medan Area dan dilaboratorium Politeknik Negeri Medan. Hasil penelitian tanah timbunan diperoleh berat jenis tanah (Gs) = 2,63 gr, Berat volume $\operatorname{tanah}$ basah $(\gamma \mathrm{b})=14,8512 \mathrm{kN} / \mathrm{m}^{3}$, Berat volume tanah kering $(\gamma \mathrm{d})=0,3236 \mathrm{kN} / \mathrm{m}^{3}$, Permeabilitas tanah $(\mathrm{K})=12,929$ $\mathrm{cm} /$ jam, tegangan geser $(\varphi)=23,61^{0}$. Kohesi tanah $(\mathrm{c})=0.057 \mathrm{~kg} / \mathrm{cm}^{2}$, Modulus elastisitas $(\mathrm{E})=2400 \mathrm{kN} / \mathrm{m}^{2}$. Kemudian dari hasil running plaxis diperoleh deformasi sebesar 0.1601 meter sedangkan yang dihasilkan dengan metode Steinbrenner penurunan yang dihasilkan sebesar 0,1232 m. yang mengakibatkan plate footing pondasi tapak patah. Tegangan yang terjadi pada tanah sebesar $0.012 \mathrm{kN} / \mathrm{m}^{2}$ dan dari hasil analisis diperoleh faktor aman (safety factor) sebesar 1 (satu).
\end{abstract}

Kata Kunci : Pengaruh Tanah Timbunan, Elemen Hingga Plaxis 2D.V20

\section{ABSTRACT}

The lower structure of a building construction consists of a foundation and a layer of soil to support the load of the upper construction. The condition of the soil under the structure is closely related to the behavior of the soil itself when it receives loads, for example failures that occur in the sub-grade of the embankment foundation, namely the foundation soil is too soft so that the carrying capacity of the soil to withstand the load of the embankment is small, as a result the settlement that occurs is too large. So the soil layer under the structure must be strong, stable, safe, so that it does not decrease, does not break, because it will be difficult to repair a foundation system. The purpose of this study was to determine the effect of embankment soil on a footing foundation and how much settlement was caused to the foundation. The Plaxis D2 V20 method is a finite element method that aims to analyze and design the geotechnical field. Soil samples were taken at the hospital. Wulan Windi, Medan City, using manual tools. The embankment soil investigation aims to determine the nature and characteristics of the embankment soil carried out at the Civil Engineering Laboratory of the Medan Area University and the Medan State Polytechnic laboratory. The results of the soil embankment research showed that the density of soil $(G s)=2.63 \mathrm{gr}$, wet soil volume weight $(\gamma \mathrm{b})=14.8512 \mathrm{kN} / \mathrm{m3}$, dry soil volume weight $(\gamma d)=0.3236$ $\mathrm{kN} / \mathrm{m} 3$, soil permeability $(K)=12,929 \mathrm{~cm} /$ hour, shear stress $(\varphi)=23,610$. Soil cohesion $(c)=0.057 \mathrm{~kg} / \mathrm{cm} 2$, Modulus of elasticity $(E)=2400 \mathrm{kN} / \mathrm{m} 2$. Then from the results of the running plaxis, the deformation is 0.1601 meters, while that of the Steinbrenner method, the resulting decrease is $0.1232 \mathrm{~m}$. which causes the plate footing of the tread foundation to fracture. The stress that occurs in the soil is $0.012 \mathrm{kN} / \mathrm{m} 2$ and from the analysis results obtained a safety factor of 1 (one). Keywords: Effect of Embankment, Finite Element Plaxis $2 D$ V20

How to Cite : Sitompul, B.D. (2021), Pengaruh Tanah Timbunan Terhadap Daya Dukung Pondasi Telapak (Square Footing). JCEBT (Journal of Civil Engineering, Building and Transportation). 5 (2): 109 - 125 


\section{PENDAHULUAN}

Struktur bawah bangunan suatu konstruksi gedung terdiri dari pondasi dan lapisan tanah untuk mendukung beban konstruksi bagian atas. Pondasi adalah adalah suatu bagian dari konstruksi bangunan yang berfungsi meletakkan bangunan dan meneruskan beban bangunan atas ke dasar tanah yang cukup kuat untuk mendukungnya (Gunawan, 2016). Timbunan adalah suatu kegiatan meletakkan atau menambah volume material yang sejenis atau material lain dengan tujuan meratakan permukaan yang berupa lubang sebelumnya dan atau meningggikan elevasi permukaan untuk mendapatkan kondisi permukaan yang lebih baik.

\section{Menurut (Surendro B, 2016)} menyatakan bila ditemui tanah yang jelek (tanah yang daya dukungnya rendah), kemudian ditempat tersebut akan didirikan suatu bangunan, maka harus dilakukan perbaikan tanah terlebih dahulu. Kadang-kadang juga ditemui lapisan tanah timbunan sampah yang masih menjalani proses pelapukan, sehingga lapisan seperti ini masih mengalami penurunan yang cukup besar, timbunan puing-puing bangunan meskipun padat, karena puing-puing bangunan campurannya tidak homogin, maka apabila bangunan diletakkan diatas lapisan tersebut, pasti akan mengalami penurunan yang cukup besar, sehingga membahayakan bangunan.

Maksud dari penelitian ini adalah untuk menganalisa berapa besar pengaruh tanah timbunan terhadap daya dukung pondasi tapak dengan memperhitungkan semua analisa data tanah dan tegangan yang timbul akibat beban pondasi dan pembebanan lainnya.

Adapun tujuan dalam penelitian ini adalah untuk mengetahui pengaruh tanah timbunan pada suatu pondasi telapak dengan menggunakan Plaxis 2D V20 dan metode Steinbrenner dan berapa besar penurunan (settlement) yang ditimbulkan terhadap daya dukung pondasi telapak.

Daya dukung tanah adalah kemampuan tanah untuk memikul tekanan atau beban maksimum yang diizinkan untuk bekerja pada pondasi. Untuk mendapat tegangan yang dipakai dalam perencanaan pondasi, besarnya beban dibagi dengan faktor keamanan (safety factor) biasanya untuk pondasi diberi 3 (tiga). Nilai yang diperoleh disebut dengan tegangan tanah yang diizinkan. Seperti pada persamaan berikut :

$$
\mathrm{q}_{\mathrm{all}}=\frac{\mathrm{qult}_{\mathrm{u}}}{\mathrm{SF}}
$$

Dimana :

qall : Tegangan tanah yang diizinkan $\left(\mathrm{kg} / \mathrm{m}^{2}\right)$ 
qult : Daya dukung batas $\left(\mathrm{kg} / \mathrm{m}^{2}\right)$

SF : Factor keamanan

Untuk dapat memahami konsep daya dukung batas suatu tanah, terlebih dahulu kita harus memahami konsep pola keruntuhan geser dalam tanah. Hubungan antara beban dan penurunan akan seperti gambar berikut :

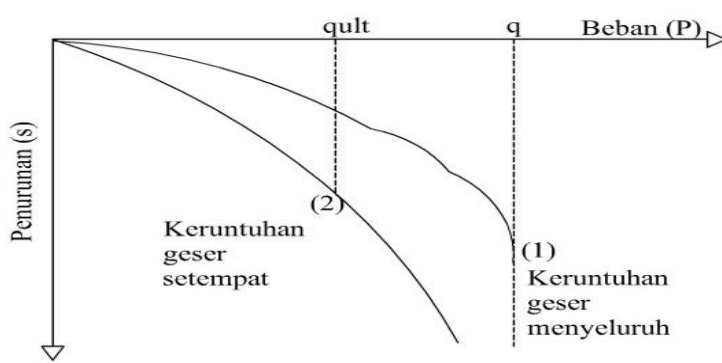

Gambar 1. Grafik hubungan antara beban dan penurunan

Menurut (Vesic, 1963), model keruntuhan geser umum diharapkan terjadi pada pondasi yang relatif dangkal yang terletak pada pasir padat atau kira-kira dengan $\varphi^{\prime}>36^{0}$, sedangkan keruntuhan geser local kira-kira $\varphi^{\prime}<290$.

Persamaan daya dukung untuk menghitung kapasitas tanah menurut Metode Terzaghi :

$\mathrm{qult}_{\mathrm{u}}=\mathrm{c} \mathrm{N}_{\mathrm{c}}+\mathrm{D} f \gamma \mathrm{N}_{\mathrm{q}}+0,5 \gamma \mathrm{BN}_{\gamma}$

Penurunan pada pondasi merupakan masalah rekayasa yang penting dan harus dianalisis bersamaan dengan estimasi daya dukungnya. Jika seluruh permukaan tanah dibawah dan disekitar bangunan turun secara seragam dan penurunan tidak terjadi berlebihan, maka turunnya bangunan akan tidak nampak oleh pandangan mata dan penurunan yang terjadi tidak menyebabkan kerusakan pada bangunan (Hardiyatmo, 2016).

Contoh-contoh kerusakan bangunan akibat penurunan tak seragam, ditunjukkan pada Gambar 2 berikut:

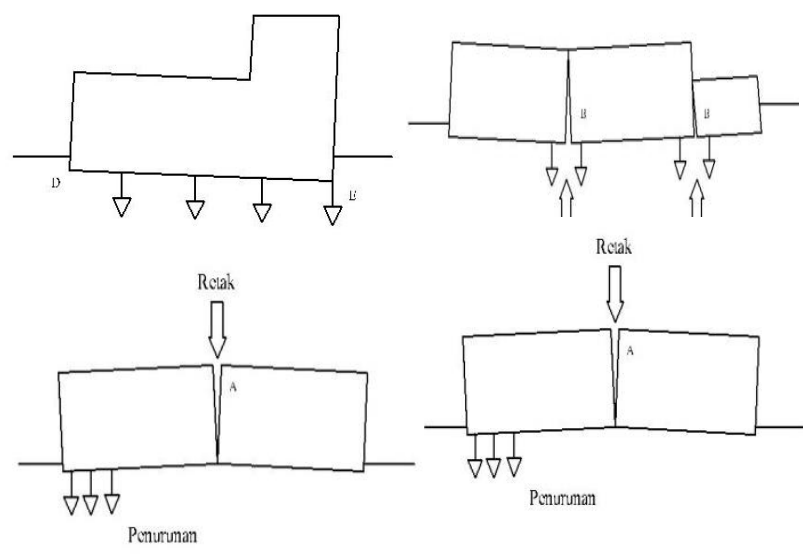

Gambar 2. Contoh kerusakan bangunan akibat penurunan

Sumber : Hardiyatmo.C.H (2017)

Pada Tabel 2.2 (Sower, 1962) diberikan batasan nilai penurunan yang dapat dijadikan acuan sebagai kriteria penurunan dalam merencanakan pondasi. Namun batasan lain yang lebih penting adalah batasan yang ditetapkan berdasarkan fungsi atau kegunaan dari bangunan itu sendiri dan juga terhadap pentingnya benda yang akan diamankan di dalam bangunan tersebut.

Tabel 1.Batas penurunan ijin (Sower, 1962)

\begin{tabular}{clc}
\hline $\begin{array}{c}\text { Tipe } \\
\text { penurunan }\end{array}$ & \multicolumn{1}{c}{ Factor pembatas } & Nilai batas \\
\hline \multirow{4}{*}{$\begin{array}{c}\text { Penurunan } \\
\text { total }\end{array}$} & Drainase & $150-300 \mathrm{~mm}$ \\
& Akses & $300-600 \mathrm{~mm}$ \\
& Perkiraan terjadi penurunan distorsi & \\
& Tembok pasangan batu & $25-50 \mathrm{~mm}$ \\
& Strutur rangka & $50-100 \mathrm{~mm}$ \\
& Silo, pondasi rakit, cerobong asap & $75-300 \mathrm{~mm}$ \\
\hline \multirow{4}{*}{ Kemiringan } & Stabilitas terhadap guling & Tergantung tinggi dan lebar \\
& Kemiringan tower, cerebong asap & $0.004 \mathrm{~L}$ \\
& Berjalannya kendaraan (truk) & $0.01 \mathrm{~L}$ \\
& Bergeraknya barang-barang & $0.01 \mathrm{~L}$ \\
& Bekerjanya mesin pemintal kapas & $0.003 \mathrm{~L}$ \\
\hline
\end{tabular}




\begin{tabular}{clc}
\hline & Pengoperasian turbin, generator & $0.0002 \mathrm{~L}$ \\
& Rail crane (mesin penganggkut) & $0.003 \mathrm{~L}$ \\
& Drainase pada muka lantai & $0.01-0.02 \mathrm{~L}$ \\
\hline \multirow{4}{*}{ Penurunan } & Tingginya pasangan batu bata & $0.0005-0.001 \mathrm{~L}$ \\
& Retakan pada dinding batu bata & $0.001 \mathrm{~L}$ \\
& Retakan pada plesteran dinding & $0.0025-0.004 \mathrm{~L}$ \\
& Bangunan rangka beton bertulang & $0.003 \mathrm{~L}$ \\
& Bangunan rangka baja menerus & $0.002 \mathrm{~L}$ \\
& Struktur rangka baja sederhana & $0.005 \mathrm{~L}$ \\
\hline
\end{tabular}

Sumber : H.Abdul (2008), Rekayasa Pondasi

Penurunan (settlement) pondasi yang berada pada tanah berbutir halus yang jenuh dapat dibagi menjadi 3 komponen, yaitu: Penurunan segera (immediate settlement), Penurunan konsolidasi primer, Penurunan konsolidasi sekunder. Penurunan total adalah jumlah dari ketiga komponen penurunan tersebut, atau bila dinyatakan dalam persamaan :

$\mathrm{S}=\mathrm{S}_{\mathrm{i}}+\mathrm{S}_{\mathrm{c}}+\mathrm{S}_{\mathrm{S}}$

Dimana :

$\mathrm{S}=$ Penurunan total

$S_{\mathrm{i}}=$ Penurunan segera

$\mathrm{S}_{\mathrm{c}}=$ Penurunan konsolidasi primer

$\mathrm{S}_{\mathrm{s}}=$ Penurunan konsolidasi sekunder

Penurunan segera (immediate settlement, Se) adalah penurunan yang terjadi pada saat pemberian beban pada masa konstruksi atau segera setelah masa konstruksi selesai. Secara sistematis dinyatakan pada persamaan berikut:

$\mathrm{S}_{\mathrm{i}}=\frac{q B}{E}\left(1-\mu^{2}\right) I_{p}$

Dimana :

$\mathrm{S}_{\mathrm{i}}=$ penurunan segera $(\mathrm{m})$

$q$ = tekanan pada dasar pondasi $\left(\mathrm{kN} / \mathrm{m}^{2}\right)$

$B$ = lebar pondasi (m)
$E=$ modulus elastis $\left(\mathrm{kN} / \mathrm{m}^{2}\right)$

$\mu=$ rasio poisson

$I_{p}=$ factor pengaruh

Tabel 2. Faktor pengaruh $I_{m}$ (Lee, 1962) dan $I_{p}$ (Schleicher, 1962) untuk pondasi kaku, dan factor pengaruh untuk pondasi fleksibel (Terzagih, 1943).

\begin{tabular}{lccccc}
\hline \multirow{2}{*}{ Bentuk pondasi } & \multicolumn{3}{c}{ Fleksibel $(I p)$} & \multicolumn{2}{c}{ kaku } \\
\cline { 2 - 6 } & pusat & sudut & $\begin{array}{c}\text { Rata- } \\
\text { rata }\end{array}$ & $I_{p}$ & $I_{m}$ \\
\hline $\begin{array}{l}\text { Lingkaran } \\
\text { Bujur sangkar }\end{array}$ & 1,00 & 0,64 & 0,85 & 0,88 & \\
Empat persegi panjang & 1,12 & 0,36 & 0,95 & 0,82 & 3,70 \\
$L / B=1,5 \quad$ & & & & \\
\multicolumn{1}{l}{2,0} & 1,36 & 0,68 & 1,20 & 1,06 & 4,12 \\
\multicolumn{1}{c}{5,0} & 1,53 & 0,77 & 1,31 & 1,20 & 4,38 \\
10,0 & 2,10 & 1,05 & 1,83 & 1,70 & 4,82 \\
100,0 & 2,52 & 1,26 & 2,25 & 2,10 & 4,93 \\
& 3,38 & 1,69 & 2,96 & 3,40 & 5,06 \\
\hline
\end{tabular}

Sumber : Hardiyatmo (2017)

Penurunan-segera pada sudut luasan beban terbagi rata empat persegi panjang fleksibel yang terletak dipermukaan, dapat dihitung dengan menggunakan persamaan yang diusulkan Steinbrenner (1934) :

$\mathrm{S}_{\mathrm{i}}=\frac{q B}{E} I_{p}$

Dimana :

$I_{p}=\left(1-\mu^{2}\right) F_{1}+\left(1-\mu-2 \mu^{2}\right) F_{2}$

Dengan $F_{1}$ dan $F_{2}$ adalah koefisienkoefisien yang diusulkan oleh Steinbrenner (1934) dalam bentuk grafik pada Gambar 3.

Penurunan disembarangan titik A (Gambar 3) pada pondasi empat persegi panjang dipermukaan tanah dengan tebal terbatas, dihitung dengan menggunakan persamaan :

$\mathrm{S}_{\mathrm{i}}=\frac{q}{E}\left(I_{p 1} \mathrm{~B}_{1}+I_{p 2} \mathrm{~B}_{2}+I_{p 3} \mathrm{~B}_{3}+I_{p 4} \mathrm{~B}_{4}\right)$ 
Dimana : $\mathrm{B}_{1}, \mathrm{~B}_{2}, \mathrm{~B}_{3}$, dan $\mathrm{B}_{4}$ adalah lebar masing-masing luasan.

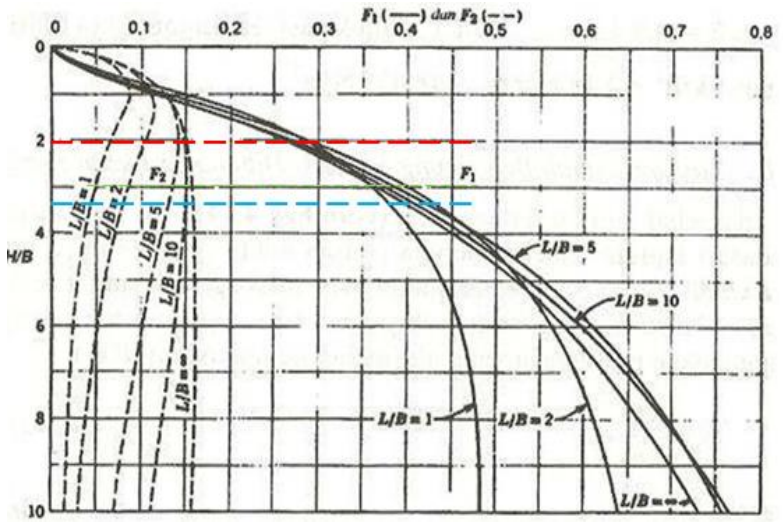

Gambar 3. Penurunan segera pada sudut luasan beban terbagi rata fleksibel dipermukaan (Steinbrenner, 1934)

Sumber : Hardiyatmo C.H (2017)

Penurunan konsolidasi primer dihitung dengan menggunakan persamaan berikut

$\mathrm{S}_{\mathrm{c}}=\frac{\Delta e}{1+e_{0}} \mathrm{H}=\frac{e_{1}-e_{0}}{1+e_{0}} \mathrm{H}$

Dimana :

$\Delta e=$ perubahan angka pori akibat pembebanan

$e_{0}=$ angka pori awal

$e_{0}=$ angka pori setelah akhir konsolidasi

$\mathrm{H}=$ tebal lapisan tanah yang ditinjau

Untuk tanah tertentu, penurunan konsolidasi primer total dinyatakan oleh persamaan-persamaan berikut. Bila didefinisikan:

$p_{1}^{\prime}=p o^{\prime}+\Delta p^{\prime}$

Penurunan untuk tanah normally consolidated $\left(p c^{\prime}=p o^{\prime}\right)$ dengan tegangan efektif sebesar $p_{1}{ }^{\prime}$
$S_{c}=C_{c} \frac{H}{1+e_{0}} \log \frac{\mathrm{p}_{1^{\prime}}}{p_{0}{ }^{\prime}}=\Delta \mathrm{e}=\mathrm{C}_{\mathrm{c}} \log \frac{p_{0}{ }^{\prime}+\Delta p}{p_{0}{ }^{\prime}}$

Untuk tanah overconsolidated $\left(p c^{\prime}>p o^{\prime}\right)$ penurunan konsolidasi primer total dinyatakan oleh persamaan yang bergantung nilai $p_{1}^{\prime}$

Bila, $p_{1}{ }^{\prime}<p_{c}{ }^{\prime}$

$S_{c}=C_{r} \frac{H}{1+e_{0}} \log \frac{\mathrm{p}_{1}{ }^{\prime}}{p_{0} \prime}$

Bila, $p_{1}{ }^{\prime}>p_{c}{ }^{\prime}$

$S_{c}=C_{r} \frac{H}{1+e_{0}} \log \frac{\mathrm{p}_{1^{\prime}}}{p_{0}{ }^{\prime}}+C c \frac{H}{1+e_{0}} \log \frac{\mathrm{p}_{1}^{\prime}}{p_{0}{ }^{\prime}}$

Dengan,

$C_{c}=\frac{\Delta \mathrm{e}}{\Delta \log \mathrm{p}^{\prime}}=\frac{e_{1}-e_{2}}{\log \left(p_{2}{ }^{\prime} / p_{1}{ }^{\prime}\right)}$

$C_{r}=\frac{\Delta \mathrm{e}}{\Delta \log \mathrm{p}^{\prime}}=\frac{e_{1}-e_{2}}{\log \left(p_{2^{\prime}} / p_{1^{\prime}}\right)}$

Dimana:

$\mathrm{S}_{\mathrm{c}}$ : Penurunan konsolidasi primer (m)

$\Delta \mathrm{e}$ : perubahan angka pori

$\mathrm{e}_{0}$ : angka pori awal

$\mathrm{H}$ : tebal lapis tanah (m)

$\mathrm{C}_{\mathrm{c}}$ : indeks pemampatan

$\mathrm{C}_{\mathrm{r}}$ : indeks pemampatan kembali

$\Delta \mathrm{p}:$ tambahan tegangan akibat beban pondasi $(\mathrm{kN} / \mathrm{m} 2)$

$p_{c}{ }^{\prime}$ : tekanan prakonsolidasi $(\mathrm{kN} / \mathrm{m} 2)$

Besar penurunanya merupakan fungsi waktu (t) dan kemiringan kurva indeks pemampatan sekunder $(C \alpha)$. Kemiringan $C \alpha$ dinyatakan dalam persamaan:

$C_{\alpha}=\frac{\Delta \mathrm{e}}{\log \left(\mathrm{t}_{2} / \mathrm{t}_{1}\right)}$ 
Rasio pemanpatan sekunder $\mathrm{C}_{\alpha \varepsilon}$ dinyatakan :

$\mathrm{C}_{\alpha \varepsilon}=\frac{C \alpha}{(1+e p)}$

Penurunan konsolidasi sekunder, dihitung dengan persamaan:

$S_{s}=\frac{C_{a}}{1+e_{p}} H \operatorname{long} \frac{\mathrm{t}_{2}}{\mathrm{t}_{1}}$

Dimana :

$\mathrm{S}_{\mathrm{s}}=$ penurunan konsolidasi sekunder

$H=$ tebal lapisan lempung

$\mathrm{e}_{\mathrm{p}}=$ angka pori saat akhir konsolidasi

primer

$\mathrm{t}_{2}=\mathrm{t}_{1}+\Delta \mathrm{t}$

$\mathrm{t}=$ saat waktu setelah konsolidasi

primer berhenti

Nilai keamanan (safety factor) yang biasanya diadopsi untuk sebuah pondasi adalah 3 (tiga). Sedangkan batas toleransi pergerakan (pergeseran dan/ atau penurunan) bervariasi tergantung kepada jenis dan fungsi bangunan yang didukung oleh sistem pondasi-tanah.

Plaxis adalah suatu program elemen batas yang secara khusus digunakan untuk analisa dari (deformasi) perubahan bentuk dan stabilitas didalam proyek rancang-bangun geoteknik.

Pada pengoperasian Plaxis 2D.V20 ini membutuhkan nilai-nilai parameter pada tanah yang di dapat dari hasil penyelidikan tanah. Data-data tersebut digunakan sebagai data input tanah.
Adapun prosedur dari program Plaxis antara lain sebagai berikut :

Menentukan title (judul), model, dan elemen pada menu bar project properties serta menuliskan perintah atau tujuan yang akan dipakai.

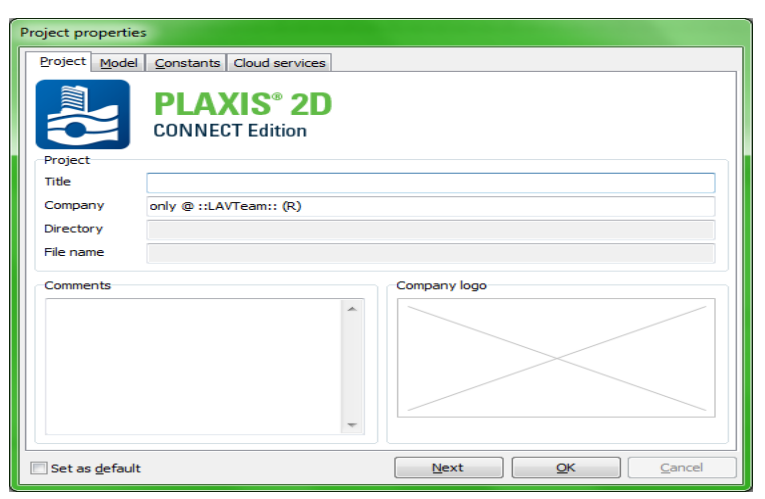

Gambar 4. Kotak project properties

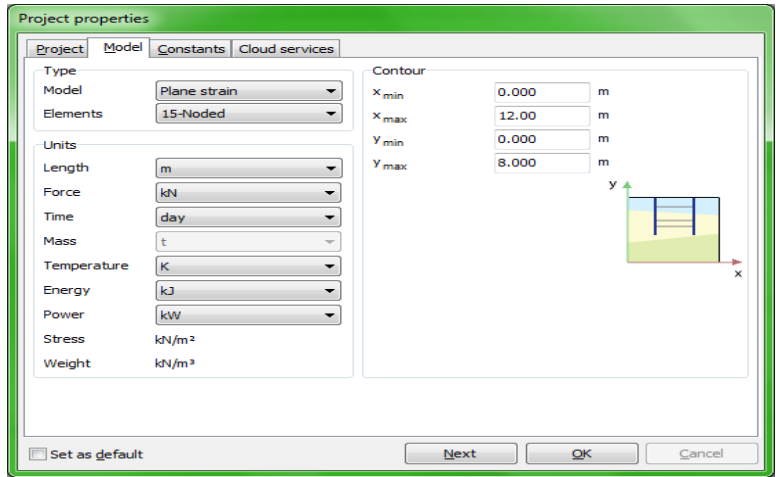

Gambar 5. Kotak project properties model

Memodelkan atau Menuliskan dimensi tanah dan parameter tanah dari kasus yang akan dipelajari, yaitu sepanjang ke kiri, ke kanan, ke atas, dan ke bawah.

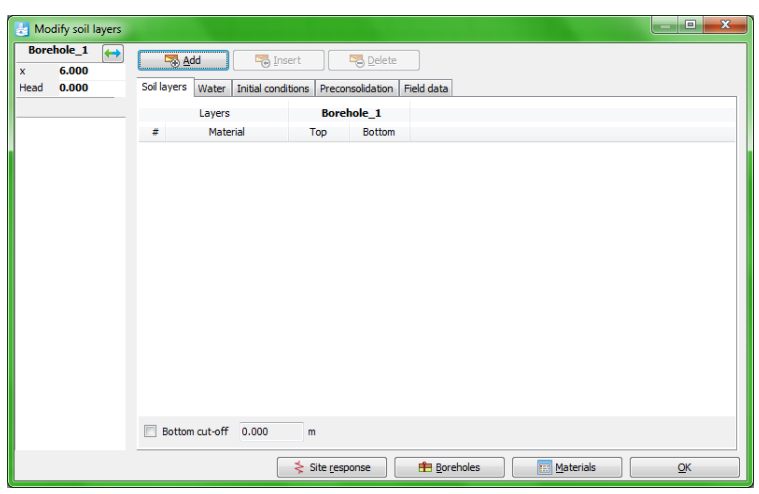

Gambar 6. Menu bar modify soil layers 
Merangkai bentuk dimensi pondasi atau plat dari tanah tadi kemudian diberi pembebanan

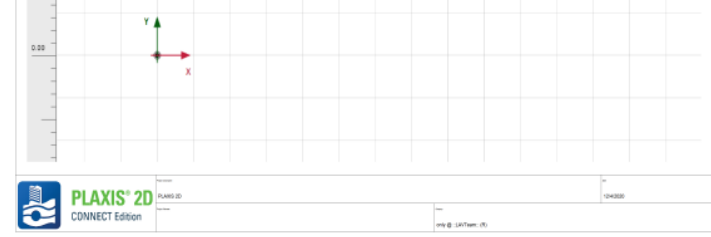

Gambar 7. Menu bar structures

setelah selesai memodelkan dimensi tanah dan pondasi, selanjutnya klik menu mesh dan melakukan generate mesh untuk melihat distribusi elemen sehingga akan tampil seperti contoh pada gambar

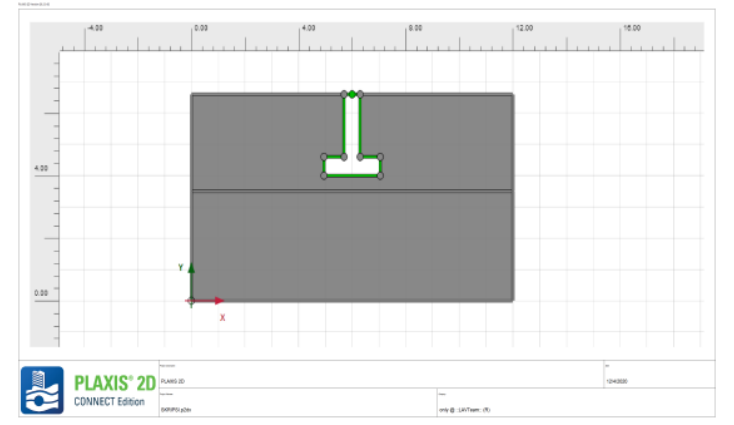

Gambar 8. Menu bar mesh

Setelah generate mesh dilakukan selanjutnya klik menu bar staged contrucsion kemudian untuk menganalisis klik calculate kemudian lakukan running.

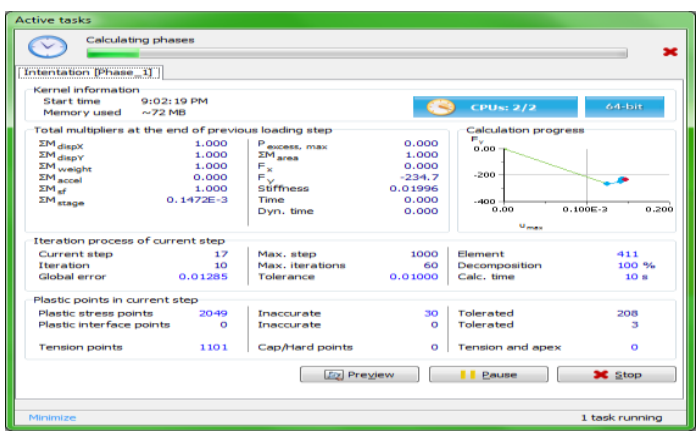

Gambar 9. Proses calculate

\section{METODE PENELITIAN}

Penyelidikan tanah dilakukan di Laboratorium Mekanika Tanah Teknik Sipil, Universitas Medan Area Sumatera Utara. Sampel tanah dalam penelitian ini yang diambil adalah tanah terganggu (disturbed soil) dengan menggunakan alat tabung shelby pada lapangan proyek pembangunan RS.Wulan Windi Medan SUMUT yang masih dalam proses pembangunan.

Lokasi pengambilan sampel tanah dan penelitian yang akan dilakukan yaitu pada proyek pembangunan RS.Wulan Windi Jl. Marelan Raya No.17, Rengas Pulau, Kec. Medan Marelan, Kota Medan, Sumatera Utara 20255.

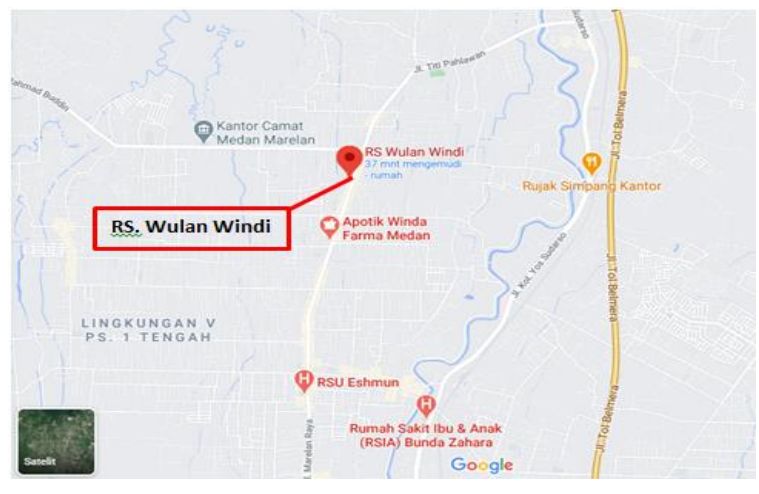

Gambar 10. Lokasi pengambilan sampel Sumber : Google maps

Adapun metode penelitian yang digunakan adalah metode elemen hingga (finite element method) yang dibantu dengan program PLAXIS 2D.V20 Dalam menganalisis menggunakan PLAXIS 2D langkah yang harus dilakukan yaitu penentuan model geometri, model material, penentuan parameter model 
dan melakukan perhitungan. Geometri pada pemodelan dibagi menjadi elemenelemen yang disebut sebagai jaringan elemen hingga. Setiap elemen memuat sejumlah titik nodal yang mempunyai sejumlah derajat kebebasan yang berkaitan dengan nilai dari parameter yang tidak diketahui dalam permasalahan nilai batas yang akan diselesaikan. Metode elemen hingga dalam PLAXIS 2D digunakan untuk menanalisis suatu keruntuhan tanah, faktor keamanan dengan mengurangi nilai kohesi dengan sudut geser.

Tujuan pengumpulan data yang memadai adalah mengevaluasi metode yang diperlukan dalam mengatasi penurunan tanah tersebut.

Berikut ini adalah kerangka berpikir pada penelitian yang akan dilakukan :

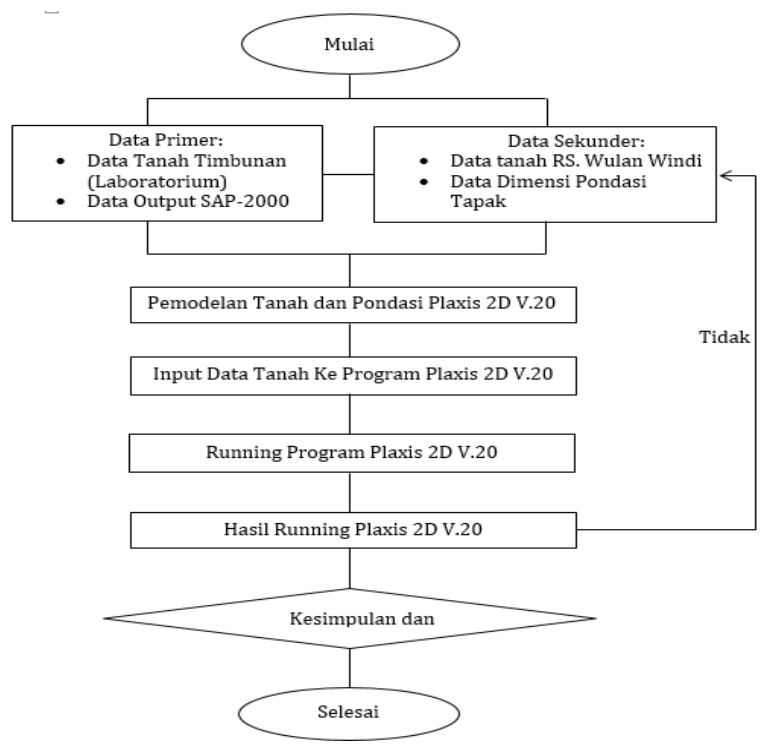

Gambar 11. Bagan kerangka berpikir

\section{HASIL DAN PEMBAHASAN}

Analisis data yang akan membahas mengenai data-data yang ada, meliputi lapisan tanah berdasar pada sifat-sifat fisik tanah $(\gamma, G s, e)$, sifat mekanik (c, $\varnothing$, v), dan permeabilitas (k). Stratifikasi tanah akan memberikan gambaran mengenai penyebaran tanah berdasar pada analisa terhadap data-data tanah yang ada. Selain data tanah diperlukan juga data yang akan digunakan untuk memodelkan pembebanan pada struktur pondasi dengan Plaxis 2D.V20. Berikut data-data tanah yang diperoleh dari hasil pengujian:

Tabel 3. Data hasil pengujian berat jenis tanah

\begin{tabular}{lccc}
\hline \multicolumn{1}{c}{ Langkah Pengujian } & Satu & \multicolumn{2}{c}{ Hasil } \\
& an & I & II \\
\hline Berat piknometer + tanah & gr & 60,0 & 43,0 \\
Berat piknometer & gr & 49,9 & 33,7 \\
Berat tanah & gr & 10,0 & 9,3 \\
Suhu t ${ }^{0} \mathrm{c}$ & ${ }^{0} \mathrm{C}$ & 30 & 30 \\
Berat piknometer + air + tanah & gr & 156,8 & 135,4 \\
Berat piknometer + air $\left(\mathrm{t}^{0} \mathrm{c}\right)$ & gr & 150,6 & 129,7 \\
Berat jenis (pada suhu $\left.{ }^{0} \mathrm{c}\right)$ & - & 2,62 & 2,64 \\
(BJ air t ${ }^{0} \mathrm{c}$ ) $/\left(\mathrm{BJ}\right.$ air $\left.27,5^{\circ} \mathrm{c}\right)$ & - & 0,999 & 0,933 \\
Berat jenis air $\left(27,5^{0} \mathrm{c}\right)$ & ${ }^{0} \mathrm{c}$ & 3 & 3 \\
Rerata berat jenis tanah & gr & 2,62 & 2,64 \\
\hline
\end{tabular}

Dari hasil pengujian berat jenis tanah yang diperoleh adalah 2,63 gram. Maka tanah diklasifikasikan kedalam jenis tanah lempung anorganik.

Tabel 4. Data hasil pengujian berat volume tanah

\begin{tabular}{lcc}
\hline \multicolumn{1}{c}{ Langkah Pengujian } & Satuan & Hasil \\
\hline Berat ring & $\mathrm{gr}$ & 17,9 \\
Berat cawan & $\mathrm{gr}$ & 13,9 \\
Berat ring + cawan + tanah basah & $\mathrm{gr}$ & 76,4 \\
Berat tanah basah & $\mathrm{gr}$ & 44,6 \\
Volume ring (r = 2,5 cm ; t =1,5 cm) & $\mathrm{cm}^{3}$ & 29,45 \\
Berat volume tanah basah & $\mathrm{gr} / \mathrm{cm}^{3}$ & 1,5144 \\
Berat ring + cawan + tanah kering & $\mathrm{gr}$ & 71,3 \\
Berat tanah kering & $\mathrm{gr}$ & 39,5 \\
Berat air & $\mathrm{gr}$ & 5,1 \\
Kadar air & $\%$ & 1,1291 \\
Berat volume tanah kering & $\mathrm{gr} / \mathrm{cm}^{3}$ & 0,033 \\
\hline
\end{tabular}




\begin{tabular}{lcc}
\hline Berat jenis tanah & - & 2,63 \\
Volume tanah kering & $\mathrm{cm}^{3}$ & 15,019 \\
Volume pori & $\mathrm{cm}^{3}$ & 14,431 \\
Volume air & $\mathrm{cm}^{3}$ & 5,1 \\
Derajat kejenuhan $(\gamma \mathrm{w}=1)$ & $\%$ & 35,34 \\
Porositas & $\%$ & 49,00 \\
Angka pori & - & 0,961 \\
\hline
\end{tabular}

Maka hasil dari pengujian tersebut

diperoleh nilai :

Berat volume tanah basah $(\gamma \mathrm{b})=1,5144$

$\mathrm{gr} / \mathrm{cm}^{3} \sim 14,8512 \mathrm{kN} / \mathrm{m}^{3}$

Berat volume tanah kering $(\gamma \mathrm{d})=0,033$

$\mathrm{gr} / \mathrm{cm}^{3} \sim 0,3236 \mathrm{kN} / \mathrm{m}^{3}$

Tabel 5. Data hasil pengujian permeabilitas tanah

\begin{tabular}{lccc}
\hline \multicolumn{1}{c}{ Pengujian } & Satuan & Sampel & Hasil \\
\hline Permeabilitas & \multirow{2}{*}{ Cm /jam } & $\mathrm{K}_{1}$ & 14,691 \\
$\quad \mathrm{~K}_{2}$ & 12,197 \\
& & $\mathrm{~K}_{3}$ & 11,953 \\
\hline Tanah $(\mathrm{K})$ & & & 38,847 \\
Rerat & & & 12,929 \\
\hline
\end{tabular}

Dari hasil perhitungan permeabilitas dengan menggunakan hukum darcy sehingga diperoleh nilai $\mathrm{K}=12,929$ $\mathrm{cm} / \mathrm{jam} \sim 3102,96 \mathrm{~m} /$ hari.

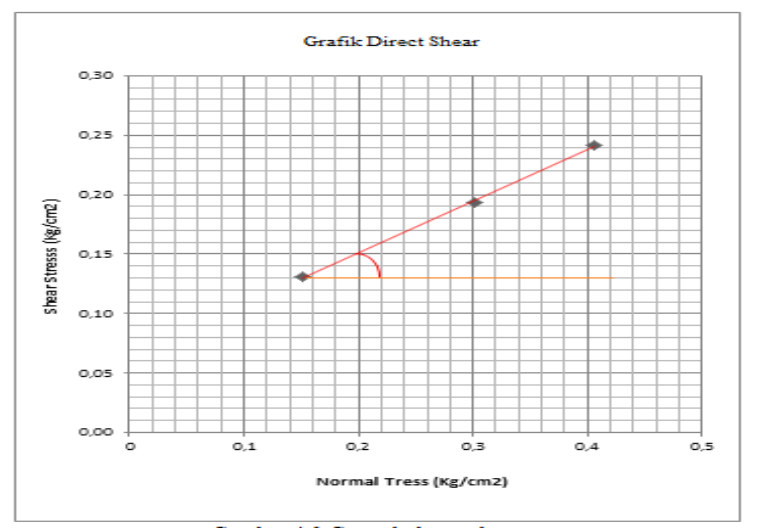

Gambar 12. Grapich direct shear

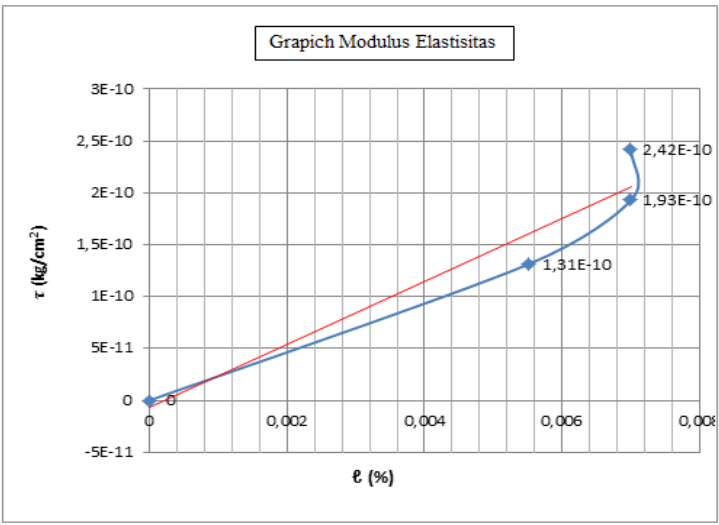

Gambar 13. Grapich modulus elastisitas

Data teknis pondasi dan beban yang bekerja :

Bahan f'c $25 \mathrm{MPa}$ bahan uji silinder

Besi beton Diameter 19 SNI (ulir) f'y 400 MPa

Diameter 10 SNI (ulir) f'y $280 \mathrm{MPa}$

Dimensi Pondasi Existing : P x L x T = 210 $\mathrm{cm} \times 210 \mathrm{~cm} \times 60 \mathrm{~cm}$

Dimensi Pedestal Existing : P x L $=60 \mathrm{~cm}$ $\mathrm{x} 40 \mathrm{~cm}$

Beban (P) : 610,509 kN (Output SAP2000)

Momen (+) : 4576,5868 kN.m

Momen (-) : :-3751,59 kN.m

Berikut adalah data detail gambar pondasi pembangunan RS. Yulan Windi : 

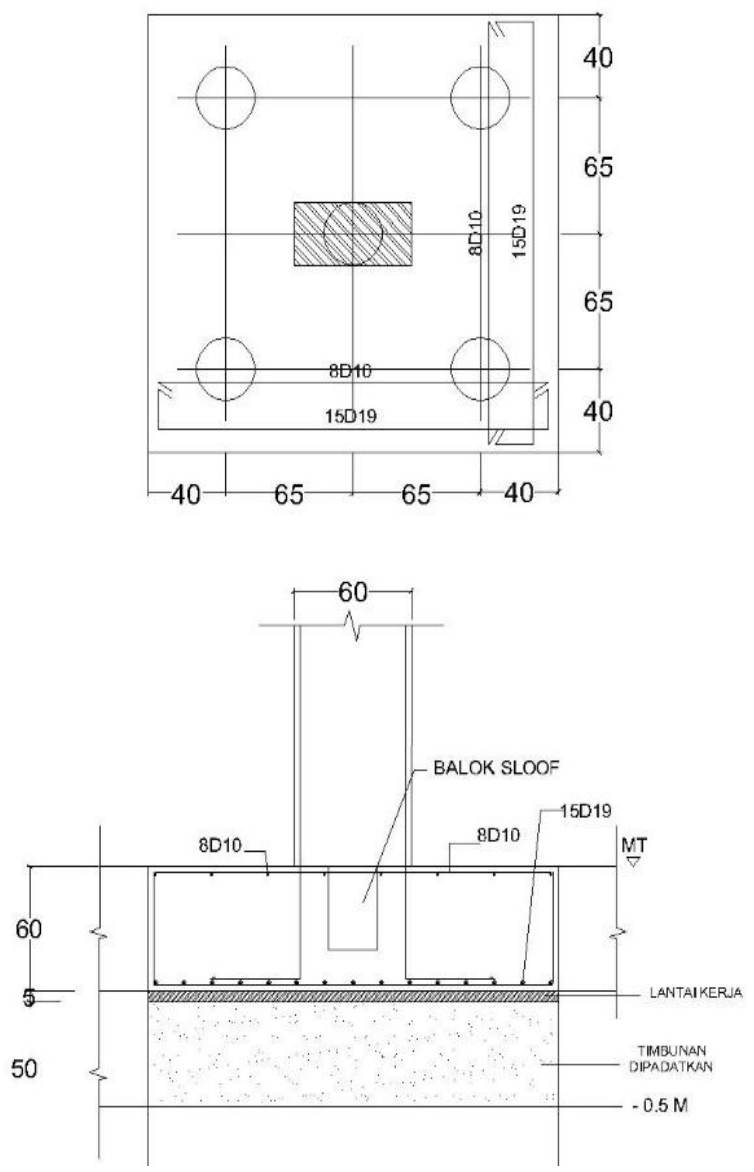

Gambar 14. Detail Pondasi Tapak

Sumber : Data RS.Wulan Windi

\section{Input Data Tanah Program Plaxis 2D.V20}

Data tanah timbunan (Lapisan tanah I ) yang akan di input kedalam Softawre Plaxis 2D V20 pada tabel berikut :

Tabel 6. Parameter Tanah timbunan data Input Plaxis 2D V20

\begin{tabular}{lccc}
\hline \multicolumn{1}{c}{ Parameter } & Simbol & Nilai & Satuan \\
\hline & & & \\
Model material & - & Nohr-coloumb & - \\
Tipe material & - & Drained & - \\
Berat volume kering & $\gamma_{\text {dry }}$ & 0.330 & $\mathrm{kN} / \mathrm{m}^{3}$ \\
Berat volume basah & $\gamma_{\text {sat }}$ & 15,144 & $\mathrm{kN} / \mathrm{m}^{3}$ \\
Permeabilitas tanah & $\mathrm{k}$ & $3.10 \mathrm{E}-06$ & $\mathrm{~m} / \mathrm{hari}^{2}$ \\
Modulus young's & $\mathrm{E}_{\text {ref }}$ & 24000 & $\mathrm{kN} / \mathrm{m}^{2}$ \\
Angka poisson & $\mathrm{V}$ & 0.30 & - \\
Kohefisitas & $\mathrm{c}_{\text {ref }}$ & 0.49 & $\mathrm{kN} / \mathrm{m}^{2}$ \\
Sudut gesek & $\varnothing$ & 23,61 & $\circ$ \\
Sudut dilatasi & $\psi$ & 0 & $\circ$ \\
\hline
\end{tabular}

Berikut adalah Data tanah (Lapisan tanah II) Rs.Wulan Windy yang diperoleh dari perusahaan pada tabel berikut :

Tabel 7. Parameter Tanah Rs.Wulan Windi

\begin{tabular}{lccc}
\hline \multicolumn{1}{c}{ Parameter } & Simbol & Nilai & Satuan \\
\hline & & & \\
Model material & - & Nohr-coloumb & - \\
Tipe material & - & Drained & - \\
Berat volume kering & $\gamma_{\text {dry }}$ & 1.608 & $\mathrm{kN} / \mathrm{m}^{3}$ \\
Berat volume basah & $\gamma_{\text {sat }}$ & 11.13 & $\mathrm{kN} / \mathrm{m}^{3}$ \\
Permeabilitas tanah & $\mathrm{k}$ & $1.46 \mathrm{E}-06$ & $\mathrm{~m} / \mathrm{hari}^{2}$ \\
Modulus young's & $\mathrm{E}_{\text {ref }}$ & 30000 & $\mathrm{kN} / \mathrm{m}^{2}$ \\
Angka poisson & $\mathrm{V}$ & 0,50 & - \\
Kohefisitas & $\mathrm{C}_{\text {ref }}$ & 0.076 & $\mathrm{kN} / \mathrm{m}^{2}$ \\
Sudut gesek & $\emptyset$ & 20.3 & $\circ$ \\
Sudut dilatasi & $\psi$ & 0 & ${ }^{\circ}$ \\
\hline
\end{tabular}

\section{Berikut adalah hasil Running Program Plaxis 2D V20}

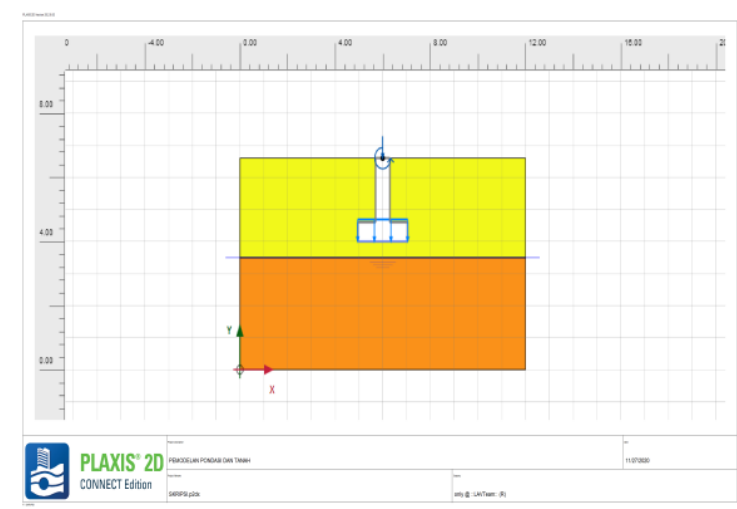

Gambar 15. Pemodelan Pondasi Dan Tanah program Plaxis 2D V.20

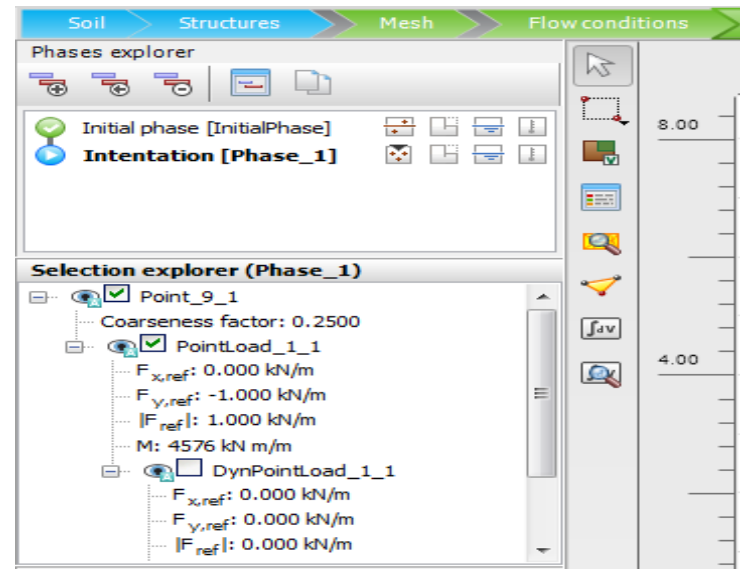

Gambar 16. Input data tanah dan beban program Plaxis 2D V.20 


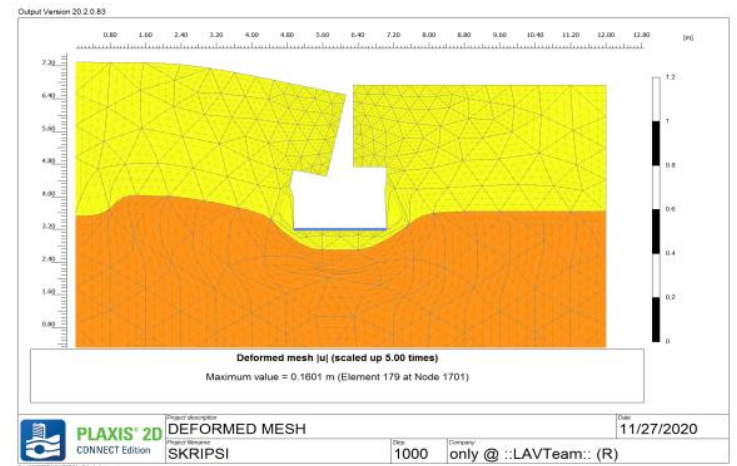

Gambar 17. Deformed Mesh

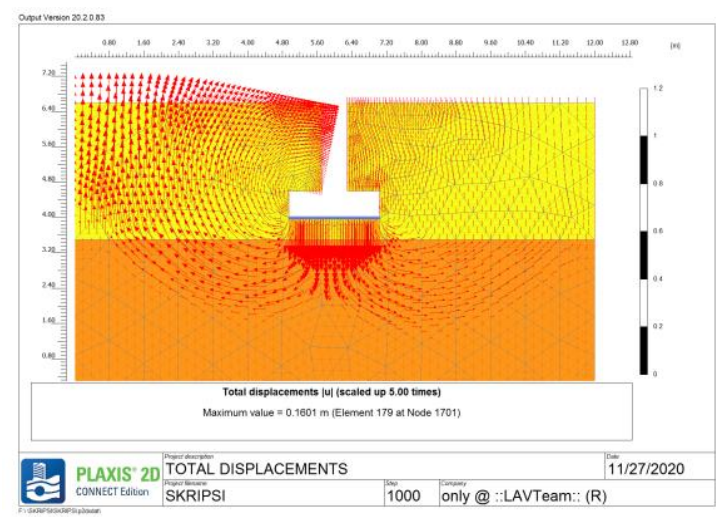

Gambar 18. Total Displacements (Arrows)

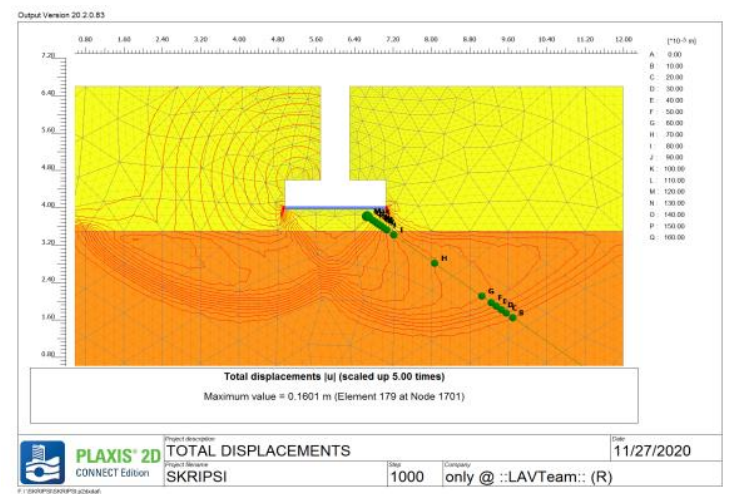

Gambar 19. Total Displacements (Contour Lines)

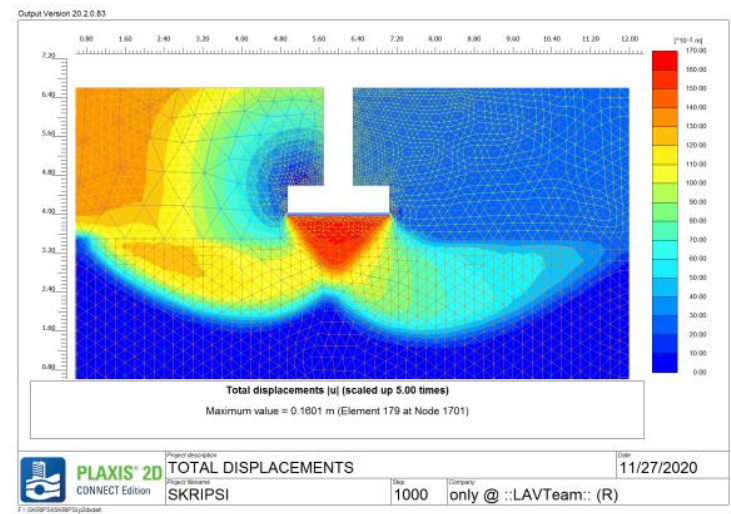

Gambar 20 . Total Displacements (Shadings)

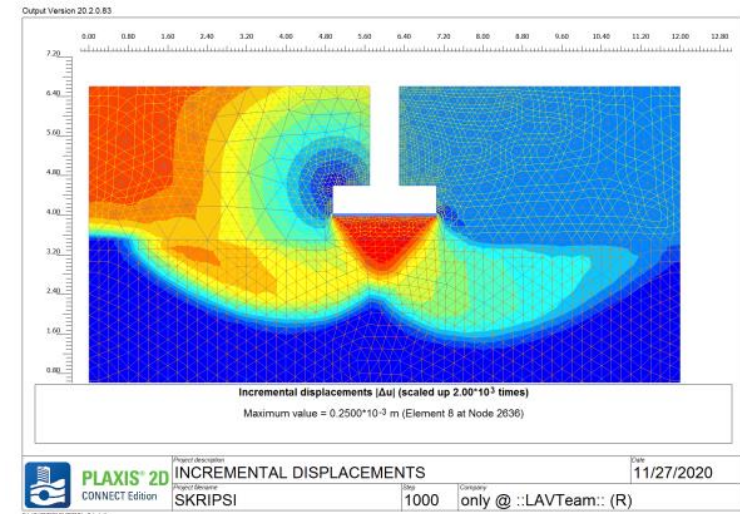

Gambar 21. Incremental Displacements

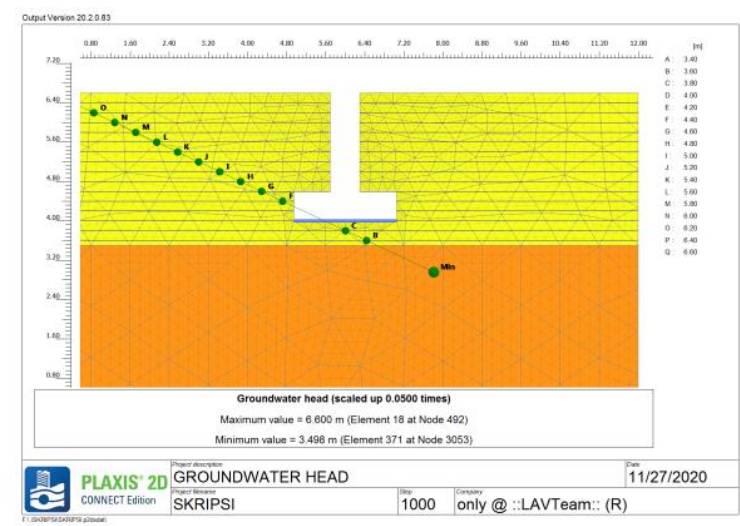

Gambar 22. Groundwater Head

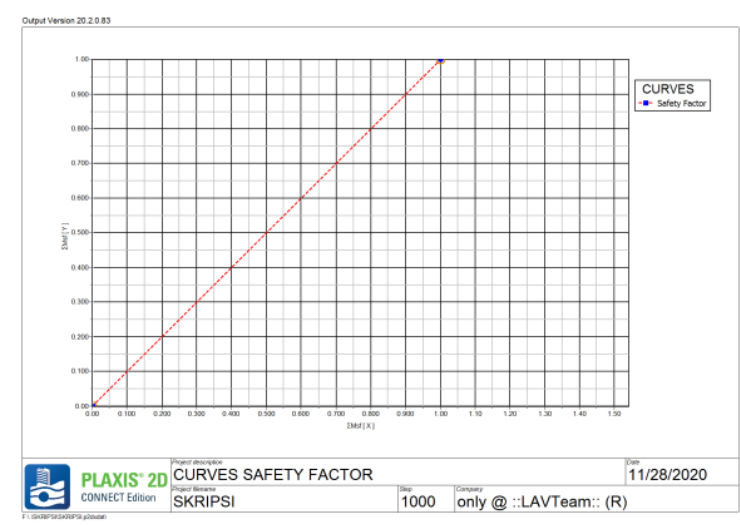

Gambar 23. Curves Safety Factor

Pada hasil running plaxis 2D.V20 (Gambar 4.6) terlihat bagaimana perlakuan dan kestabilan tanah timbunan terhadap daya dukung pondasi yang mengakibatkan terjadinya deformasi lebih besar yaitu $0.1601 \mathrm{~m}$ dan menyebabkan terjadinya patahan pada plat pondasi dimana hal ini pada program 
plaxis mengabaikan adanya material baja pada kombinasi beton sehingga pada running plaxis terlihat adanya patahan pada plat dasar pondasi.

Dengan penurunan sebesar 0,1601 meter atau $160,1 \mathrm{~mm}$ maka sesuai tabel Batas penurunan ijin (Sower, 1962) maka penurunan tersebut termasuk pada penurunan total.

Untuk mengetahui tahanan geser tanah digunakan dengan persamaan MohrCoulomb.

Diketahui :

Parameter data tanah pada lapisan tanah II :

$\mathrm{c}=0.49$

$\phi=23,61$

$\sigma=\mathrm{H} 1 . \gamma_{\mathrm{sat}}$

$$
=0,5 \cdot 15,144=7,572 \mathrm{kN} / \mathrm{m}^{2}
$$

Penyelesaian :

$$
\begin{aligned}
\boldsymbol{\tau} & =0.49+7,572 \cdot \tan \left(23,61^{\circ}\right) \\
& =3,7997 \mathrm{kN} / \mathrm{m}^{2}
\end{aligned}
$$

Untuk Tegangan efektif tanah :

$$
\begin{aligned}
\sigma_{\text {total }} & =\mathrm{H} 1 \cdot \gamma_{\mathrm{sat}}+\mathrm{H} 2 \cdot \gamma_{\mathrm{dry}} \\
& =0,5 \cdot 15,144+3,5 \cdot 1,608 \\
& =7,572+5,628 \\
& =13,2 \mathrm{kN} / \mathrm{m}^{2} \\
\mu \quad & =\mathrm{H} \cdot \gamma_{\mathrm{dry}} \\
= & 4 \cdot 1,608 \\
= & 6,432 \mathrm{kN} / \mathrm{m}^{2}
\end{aligned}
$$

Penyelesaian :

$$
\begin{aligned}
\sigma^{\prime} & =\sigma-\mu \\
& =13,2-6,432
\end{aligned}
$$

$$
=6,768 \mathrm{kN} / \mathrm{m}^{2}
$$

Tambahan tegangan pada kedalaman lapisan $\operatorname{tanah}(\mathrm{r})=05 \mathrm{rm}$

Diketahu : $\quad \Delta \sigma \mathrm{z}=\frac{Q}{(L+z)(B+z)}$

$$
\begin{aligned}
& \mathrm{Q}=610,509 \mathrm{kN} \\
& \mathrm{L}=2,1 \mathrm{~m} \\
& \mathrm{Z}=0,5 \mathrm{~m}
\end{aligned}
$$

Penyelesaian :

$$
\Delta \sigma \mathrm{Z}=\frac{610,509 \mathrm{kN}}{(2,1+0,5)(2,1+0,5)}
$$

$$
=90,31 \mathrm{kN} / \mathrm{m}^{2}
$$

Untuk mengetahui Kapasitas dukung ultimit (ultimit bearing capacity) digunakan

$$
\mathrm{qult}_{\mathrm{u}}=\frac{\mathrm{Pu}}{A}
$$

Diketahui :

$$
\mathrm{Pu}=610,509 \mathrm{kN} \text { (Output SAP-2000) }
$$

$\mathrm{A}=2,1 \mathrm{~m} \times 2,1 \mathrm{~m}$

$$
=4,41 \mathrm{~m}^{2}
$$

Penyelesaian :

qult $=\frac{610,509 \mathrm{kN}}{4,41 \mathrm{~m}^{2}}=138,44 \mathrm{kN} / \mathrm{m}^{2}$

Analisis kapasitas dukung ultimit dengan menggunakan Metode Terzaghi :

$q_{\text {ult }}=2 /{ }_{3} \mathrm{C} \mathrm{Nc^{ \prime }}+\rho_{0} \mathrm{Nq}^{\prime}+0,5 \gamma$ B.N $\gamma^{\prime}$ 
Sudut gesek dalam tanah yang digunakan dalam hitungan adalah $\phi$ pada dasar fondasi, yaitu $\phi=20^{\circ}<29^{0}$. Maka dianggap terjadi keruntuhan geser lokal, dari Tabel 2.8 diperoleh nilai :

$\mathrm{Nc}=17,69 ; \mathrm{Nq}=7,44 ; \mathrm{N} \gamma=4,97$

Diketahui :

Data tanah 1 :

$\gamma_{1}=10,13 \mathrm{kN} / \mathrm{m}^{3} ; \mathrm{c}_{1}=0,49$

$\mathrm{kN} / \mathrm{m}^{2} ; \phi_{1}=23^{0}$

Data tanah 2 :

$\gamma_{2}=14,14 \mathrm{kN} / \mathrm{m}^{3} ; \mathrm{c}_{2}=0,076 \mathrm{kN} / \mathrm{m}^{2} ; \phi_{2}$

$=20^{\circ}$

$\rho_{0}=\mathrm{D} f \cdot \gamma_{1}$

$=1 \mathrm{~m} \cdot 10,13 \mathrm{kN} / \mathrm{m}^{3}$

$=10,13 \mathrm{kN} / \mathrm{m}^{2}$

Penyelesaian :

qult $=2 / 30,076 \cdot 17,69+10,13 \cdot 7,44+0,5$.

$$
\begin{aligned}
& 14,14 \cdot 2,1 \cdot 4,97 \\
= & 0,896293+75,3672+73,78959 \\
= & 150 \mathrm{kN} / \mathrm{m}^{2}
\end{aligned}
$$

Tekanan pondasi netto, $\left(\mathrm{q}_{\mathrm{n}}\right)$

$=\mathrm{q}-\mathrm{D} f \cdot \gamma_{\mathrm{b}}$

$=138,44-(1 \times 15,144)$

$=123,3 \mathrm{kN} / \mathrm{m}^{2}$

Penurunan di pusat pondasi (A) pada denah pondasi, dihitung dengan persamaan Steinbrenner, maka pondasi dipecah menjadi 4 bagian yang sama:

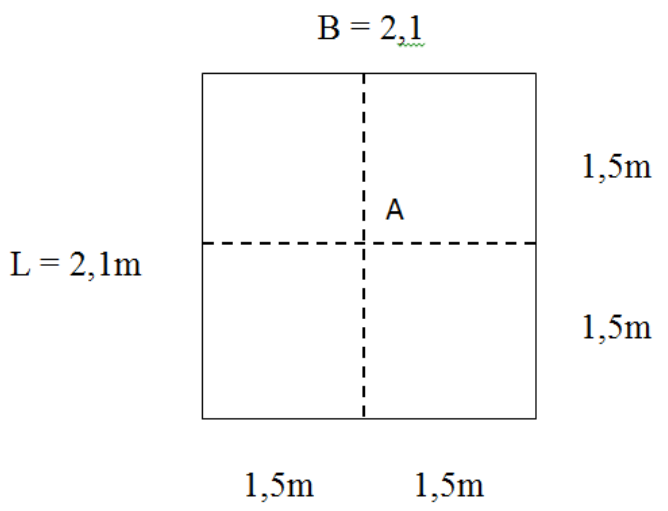

Pada denah pondasi diperoleh :

$$
\begin{aligned}
& \mathrm{L}_{1}=2,1 / 2,1=1 ; \mathrm{B}_{1} \\
& \begin{aligned}
I_{p} & =\left(1-\mu^{2}\right) F_{1}+\left(1-\mu-2 \mu^{2}\right) F_{2} \\
& =\left(1-0,3^{2}\right) F_{1}+\left(1-0,3-2.0,3^{2}\right) F_{2} \\
& =0,91 F_{1}+0,52 F_{2}
\end{aligned} \\
& H_{1} / B_{1}=0,5 / 1=0,5 \\
& L_{1} / B_{1}=1
\end{aligned}
$$

dari Gambar 2.18 (Steinbrenner, 1934), diperoleh $F_{1}=0,15$ dan $F_{2}=0,09$ maka,

$$
\begin{aligned}
I_{p} & =0,91 F_{1}+0,52 F_{2} \\
& =(0,91 \times 0,15)+(0,52 \times 0,09) \\
& =0,1818
\end{aligned}
$$

Maka, penurunan segera di pusat pondasi (titik A) :

$$
\begin{aligned}
S_{i} & =\frac{q_{n} B_{1}}{E}\left(4 \times I_{p}\right) \\
& =\frac{106,64 \times 1}{24000}(4 \times 0,1818) \\
& =0,0038 \mathrm{~m}
\end{aligned}
$$

Penurunan Lapisan Kedua: 
Dianggap lapisan tanah kedua tebal $H_{2}=4$

m (dibawah dasar pondasi), dengan

Poisson rasio, $\mu=0,5$; Elastisitas tanah, $\mathrm{E}$ $=30000 \mathrm{kN} / \mathrm{m}^{2}$, maka:

$I_{p}=0,75 F_{1}$

$H_{2} / B_{1}=4 / 1=4$

$L_{1} / B_{1}=1$

dari Gambar 2.18 (Steinbrenner, 1934),

diperoleh $F_{1}=0,41$

jadi,

$$
\begin{aligned}
I_{p} & =0,75 F_{1} \\
& =0,75 \times 0,41 \\
& =0,3075 \\
S_{\mathrm{i} 2} & =\frac{q_{n} B_{1}}{E}\left(4 \times I_{p}\right) \\
& =\frac{123,3 \times 1}{30000}(4 \times 0,3075) \\
& =0,0050 \mathrm{~m}
\end{aligned}
$$

Penurunan lapisan kedua tebal $H_{1}=3,5 \mathrm{~m}$ (dibawah dasar pondasi) dengan Poisson rasio, $\mu=0,5$; Elastisitas tanah, $\mathrm{E}=30000$ $\mathrm{kN} / \mathrm{m}^{2}$, maka:

$H_{2} / B_{1}=3,5 / 1=3,5$

$L_{1} / B_{1}=1$

dari Gambar 2.16 (Steinbrenner, 1934), diperoleh $F_{1}=0,39$

jadi,

$$
\begin{aligned}
I_{p} & =0,75 F_{1} \\
& =0,75 \times 0,39 \\
& =0,2925
\end{aligned}
$$

$$
\mathrm{S}_{\mathrm{i} 1}=\frac{q_{n} B_{1}}{E}\left(4 \times I_{p}\right)
$$

$$
\begin{aligned}
& =\frac{123,3 \times 1}{30000}(4 \times 0,2925) \\
& =0,0048 \mathrm{~m}
\end{aligned}
$$

Penurunan segera pada lapisan kedua dengan tebal $\left(\mathrm{H}_{2}-\mathrm{H}_{1}\right)$, adalah

$$
\begin{aligned}
S_{i} & =S_{i 2}-S_{i 1} \\
& =0,0050-0,0048 \\
& =0,0002 \mathrm{~m}
\end{aligned}
$$

Penurunan Konsolidasi :

Tekanan overburden efektif ditengahtengah lapisan kedua dihitung

$$
\begin{aligned}
P_{o}{ }^{\prime} & =(1,5 \times 15,144)+(1,75 \times 9,72) \\
& =39,726 \mathrm{kN} / \mathrm{m}^{2}
\end{aligned}
$$

luasan pondasi dibagi menjadi 4 bagian sama besar, dengan:

$B_{1}=L_{1}=2,1 / 2,1=1$

$m=n=B_{1} / z=L_{1} / z=1 /(3,5+1,75)=$

$0,19 \mathrm{~m}$

dari Gambar 2.13 (U. S.Navy. 1971) diperoleh $I=0,022$

Tambahan tegangan di bawah pusat pondasi:

$\Delta p=\Delta \sigma_{\mathrm{z}}=4 I q=4 \times 0,022 \times 123,2=10,85$ $\mathrm{kN} / \mathrm{m}^{2}$

Karena $p_{c}{ }^{\prime}=27 \mathrm{kN} / \mathrm{m}^{2} \leq P_{o}^{\prime}=39,726$ $\mathrm{kN} / \mathrm{m}^{2}$, maka tanah termasuk lempung terkonsolidasi normal (normally consolidated).

Maka, perubahan angka pori akibat konsolidasi total : 


$$
\begin{aligned}
\Delta \mathrm{e} & =\mathrm{C}_{c} \log \frac{p_{0}{ }^{\prime}+\Delta p}{p_{0}{ }^{\prime}} \\
& =0,45 \log \frac{39,726+10,85}{39,726} \\
& =0,0472 \mathrm{~m}
\end{aligned}
$$

Jadi, penurunan konsolidasi total :

$$
\begin{aligned}
\mathrm{S}_{\mathrm{c}} & =\frac{\Delta e}{1+e_{0}} H \\
& =\frac{0,0472}{1+1,308} 3,5 \\
& =0,072 \mathrm{~m}
\end{aligned}
$$

Maka penurunan total :

$$
\begin{aligned}
S_{t} & =0,8\left(S_{i}+S_{i}\right)+S_{c} \\
& =0,8(0,0038+0,0002)+0,072 \\
& =0,0752 \mathrm{~m}
\end{aligned}
$$

Penurunan konsolidasi sekunder terjadi pada tegangan efektif setelah penurunan konsolidasi primer berhenti.

Data-data uji konsolidasi yang diperoleh dari data proyek sebagai berikut:

Perubahan angka pori akibat perubahan, $\Delta \mathrm{e}=0,0472 \mathrm{~m}$

Waktu setelah konsolidasi primer berhenti, $t=214,3$

$\mathrm{t}_{1}=95,256 ; \mathrm{t}_{2}=138,624$

Tebal benda uji, $H=2 \mathrm{~cm}$

Angka pori saat akhir konsolidasi primer, $e_{p}=0,9819$

Penyelesaian :

Kemiringan $C \alpha$ menggunakan Persamaan:

$$
\begin{aligned}
C_{\alpha} & =\frac{\Delta \mathrm{e}}{\log \left(\mathrm{t}_{2} / \mathrm{t}_{1}\right)} \\
& =\frac{0,0472}{\log (138,624 / 95,256)} \\
& =0,29
\end{aligned}
$$

Jadi, Rasio pemampatan sekunder :

$$
\begin{aligned}
C_{\alpha \varepsilon} & =\frac{C \alpha}{(1+e p)} \\
& =\frac{0,29}{(1+0,9819)} \\
& =0,146
\end{aligned}
$$

Maka, penurunan konsolidasi sekunder :

$$
\begin{aligned}
S_{S} & =C_{\alpha \varepsilon} H \operatorname{long} \frac{\mathrm{t}_{2}}{\mathrm{t}_{1}} \\
& =0,146 \times 2 \times \operatorname{long} \frac{138,624}{95,256} \\
& =0,048 \mathrm{~m}
\end{aligned}
$$

Dari hasil perhitungan yang dilakukan dimana diperoleh nilai penurunan segera, penurunan konsolidasi primer dan sekunder didapat. maka, diperoleh penurunan total menggunakan metode Steinbrenner adalah:

$$
\begin{aligned}
S & =\left(S_{i}+S_{c}\right)+S_{S} \\
& =0,0752+0,048 \\
& =0,1232 \mathrm{~m}
\end{aligned}
$$

Dari kedua metode maka hasil analisis tersebut diperoleh perbandingan yang tidak terlalu signifikan dengan interval 0,0369 meter atau $0.000369 \mathrm{~cm}$, hal ini bisa dikatakan bahwa perhitungan baik secara konvensional (teori) maupun dengan program Plaxis 2D.V20 bisa digunakan dalam perhitungan yang 
berkaitan geoteknik di lapangan. Dengan penurunan yang terjadi cukup besar maka disimpulkan bahwa tanah timbunan yang digunakan pada pembangunan RS.Wulan Windi kurang baik dan belum dapat mengakomodasi tegangan pada pondasi tapak yang digunakan sesuai dengan analisis perhitungan.

\section{SIMPULAN}

Kesimpulan yang dapat diperoleh dari hasil analisis pengarug tanah timbunan terhadap daya dukung pondasi tapak adalah sebagai berikut :

1. Pondasi dengan adanya timbunan mengalami deformasi yang dihasilkan plaxis 2D.V20 sebesar $0.1601 \mathrm{~m}$ sedangkan yang dihasilkan dengan metode Steinbrenner penurunan yang dihasilkan sebesar $0,1232 \mathrm{~m}$.

2. Dari kedua metode yang digunakan diperoleh perbandingan yang tidak terlalu signifikan dengan interval 0,0369 meter atau $0.000369 \mathrm{~cm}$.

3. Dari hasil penurunan tersebut maka tanah timbunan yang digunakan pada proyek tersebut kurang mencukupi daya dukung pondasi karena penurunan nya termasuk kategori besar.

4. Dari hasil running Plaxis D2 V20, diperoleh faktor aman (safety factor) sebesar 1 (satu) dengan kata lain tidak memenuhi. hal ini disebabkan data input yang digunakan untuk Plaxis adalah material beton, sedangkan material baja pada pondasi tidak diperhitungkan maka pada saat adanya timbunan tertentu beton akan menekan keatas dan mengakibatkan pondasi dibawahnya patah.

5. Tegangan yang terjadi pada tanah sebesar $0.012 \mathrm{KN} / \mathrm{m}^{2}$. Perbedaan tegangan efektif tanah yang terjadi pada pondasi tapak tidak berpengaruh secara signifikan karena pemodelan pada plaxis lebih mengarah kepada faktor aman dan deformasi tanah yang terjadi pada pondasi tapak .

\section{DAFTAR PUSTAKA}

Bowles, J. E. (1992). Analisa Dan Desain Pondasi. Jakarta: Erlangga.

Budi, S. G. (2011). Pondasi Dangkal. Yogyakarta: C.V Andi Offset.

Das, B. M. (2018). Mekanika Tanah (Prinsip Prinsip Rekayasa Geoteknis) Edisi Keempst Jilid 1. Surabaya: Erlangga.

Departemen Pekerjaan Umum. (2007). Pelatihan Soilmechanics of Road Construction Engineer. jakarta: KemenPUPR RI.

Endra Ade Gunawan Sihotang, R. (2013). Desain Pondasi Telapak Dan Evaluasi . Retrieved april 23, 2020, from https://jurnal.usu.ac.id/index.php/jts/art icle/view/6131.

Gunadarma Nazir, M. (2014). Metode Penelitian. Jakarta: Ghallia Indoneisa.

H. Abdul. (2008). Rekayas Pondasi. Sumbar: CV. Bintang Grafika.

Hadiharja, J. (2010). Pondasi Dangkal Dan Pondasi Dalam. Jakarta: Guna Darma. 
Hardiyatmo, H. C. (2010). Mekanika Tanah Ii. Yogyakarta: Gadjah Mada University Press.

Hardiyatmo, H. C. (2017). Analisa Dan Perancangan Pondasi I. Yogyakarta: Gadjah Mada University Press.

Hardiyatmo, H. C. (2018). Analisa Dan Perancangan Pondasi 1. Yogyakarta: Gadjah Mada University Press.

Indra Noer Hamdhan, F. (2019). Analisis Perkuatan Timbunan Di Atas Tanah Lunak Menggunakan Dinding Turap dengan. Retrieved april 23, 2020, from https://www.researchgate.net/publicatio n/335100959_Analisis_Perkuatan_Timbu.

Kurnia, A. L. (2017). Pengaruh Beban Tanah TimbunanTerhadap Daya Dukung Pondasi Rakit Menggunakan Program Plaxis. Retrieved februari 5, 2020, from http://digilib.unila.ac.id/28340/3/SKRIP SI\%20TANPA\%20BAB\%20PEMBAHASA N.pdf. .
Martini. (2009). Pengaruh Tingkat Kepadatan Tanah Terhadap Daya Dukung Tanah. Retrieved april 21, 2020, from https://media.neliti.com/media/publicati ons/222059-pengaruh-tingkatkepadatan-tanah-terhada.pdf.

R.B, J. B. (2020). PLAXIS. Belanda: Delft University Of Technology \& PLAXIS.

Satrya Kurniawan Siregar, Rio Ritha Sembiring, \& Kamaluddin Lubis. (2004). Analisa Perhitungan Daya Dukung Pondasi Tiang Pancang. ARBITEK.

Soedarmo, G. D., \& Edy Purnomo, S. J. (2001). Mekanika Tanah 1. Malang: Kanisius.

Surendro, B. (2015). Rekayasa Pondasi. Magelang: Graha Ilmu. 